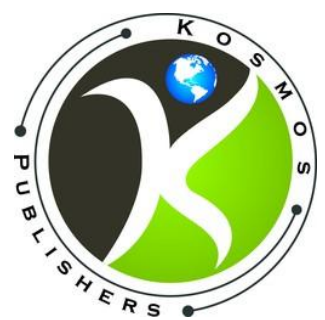

www.kosmospublishers.com

contact@kosmospublishers.com

DOI: 10.37722/AAHAE.2021401

Research Article

Advances in Agriculture, Horticulture and Entomology

ISSN 2690-1900

\title{
In Vitro Propagation of Acacia Hybrid from Axillary Buds
}

\author{
Pattama Tongkok $^{1 *}$, Jittraporn Chusrisom ${ }^{1}$, Pussadee Sukpiboon ${ }^{1}$, Eakpong Tanavat $^{1}$, Pavina \\ Badan $^{1}$, Kasem Haruthaithanasan ${ }^{1}$, Tepa Phudphong1, Weerasin Sonjaroon ${ }^{2}$, Yuttana Banchong ${ }^{1}$ \\ and Chatcharee Kaewsuralikhit ${ }^{3}$ \\ ${ }^{1}$ Kasetsart Agricultural and Agro-industrial Product Improvement Institute (KAPI), Kasetsart University, \\ Bangkok, Thailand \\ ${ }^{2}$ School of Integrated Science, Kasetsart University, Bangkok, Thailand \\ ${ }^{3}$ Kasetsart University Research and Development Institute, Kasetsart University, Bangkok, Thailand
}

Received Date: April 10, 2021; Accepted Date: April 15, 2021; Published Date: April 22, 2021;

*Corresponding author: Pattama Tongkok, Kasetsart Agricultural and Agro-industrial Product Improvement Institute (KAPI), Kasetsart University, Bangkok, Thailand. Email: aappat@ku.ac.th

\section{Abstract}

Acacia hybrid is a fast-growing tree species which plants in the forest plantation for energy in Southeast Asia, including Thailand. The efficient method for rapid propagation for forest plantation is tissue culture technology. A sterilization is one of the most important steps in tissue culture. The effects of type, concentration, and duration of disinfectants were examined. Axillary bud was used as explant for in vitro propagation. The procedures for sterilization were conducted six treatments and cultured in $1 / 2 \mathrm{MS}$ for 4 weeks. There was significantly different for all treatments in the percentage of survival, contamination, dead explants, and growth performance $(\mathrm{P}<0.05)$. The optimal sterilization procedure was rinsed in running water for 5 minutes $+20 \%$ dishwashing liquids $+70 \%$ (v/v) Ethanol for 30 seconds $+0.1 \% \mathrm{HgCl}_{2}$ for 10 minutes and rinsing with sterile water for 4 times. The results showed $13.50 \pm 9.26 \%$ contaminated explants and $86.50 \pm 9.26 \%$ survived explants. The shoot length, leaf length and leaf number were $3.40 \pm 0.20$ cm., $5.04 \pm 0.70 \mathrm{~cm}$. and $3.3 \pm 0.48$ no./explant, respectively. Axillary bud from sterilized explant was transferred to MS medium supplemented with $30 \mathrm{~g} / 1$ sucrose+0.6 mg/l BAP+0.6 $\mathrm{mg} / \mathrm{l} \mathrm{NAA}+0.3 \mathrm{mg} / \mathrm{l} \mathrm{PVP}$ for shoot multiplication. The maximum number of shoots after 8 weeks was $10.5 \pm 1.06$ shoots/explant. Each microshoot was elongated and rooted on MS basal medium without plant growth regulators.
Keywords: Acacia, Axillary Bud; Disinfectants; Fast-Growing Tree; Tissue Culture

\section{Introduction}

Industrial forest plantations are playing an important role in the economic, social, environmental, and cultural lives (Thomson et al, 2018). There are many fast-growing tree species in Thailand which are endemic and exotic species, and have been using for energy purpose (Corvanich, 1982), for example Acacia hybrid. This species is a fast-growing tree species which grows in Indonesia, Malaysia, Thailand, Vietnam, and China (Rufelds, 1987, 1988; Doughty, 2000; FAO, 1982; Potts and Dungey 2004). The Acacia hybrid is a cross between Acacia mangium and A. auriculiformis which is a medium-sized tree that looks similar to $A$. mangium. The $A$. hybrid has been introduced to many countries and it is nowadays grown in Oceania and South-East Asia due to its rapid growth and high production. Moreover, this species is among the most useful of tropical trees with its good coppicing ability, and adaptability to a range of tropical environments. This tree can reach 8 to $10 \mathrm{~m}$ and 7.5 to $9.0 \mathrm{~cm}$ DBH. in 2 years (Kijkar, 2003; Kha and Ha, 2017; Maliwan et al, 2010). It has a slightly higher wood density ( $0.455 \mathrm{~g}$ per $\mathrm{cm}^{3}$ ), and is good for production paper production, medium density fiber board, oriented-strand board, furniture, and nitrogen-fixing (Kha, 2001; Nor Asmah, 2012). Therefore, it 
is the main species was recommended to grow in Thailand for industrial forest plantations (Kha et al. 1993; Maliwan, 2010).

Almost all of the Acacia hybrid in Thailand were collected from natural stands in public land and farmland. Their productivity is not enough to supply all factory and power plant in the country. Recently, plantation forestry of Acacia hybrid in Thailand supplies high-quality raw material for bioenergy, it can reduce the pressure on native forests. Forest plantation of Acacia hybrids is not only for reforestation and short - term harvest but also for increasing local people's income, it has also contributed significantly to environmental improvement (Kha and Ha, 2017). In Thailand, increasing the forest productivity and the quality of wood products by $A$. hybrid has become increasingly important to the forest industry. In addition, this species is capable of increasing soil fertility by undergoing in a symbiotic association with Rhizobium. Therefore, it was planted among crops for alternative agriculture of agriculturist (Kha, 2001; Nor Asmah, 2012; Skolmen, 1986).

Propagation of this species has been carried out mainly from seed. However, seed collected from Acacia hybrid trees is highly variable. Therefore, plant tissue culture technology has a potential to overcome this problem where it allows efficient and rapid clonal propagation of many economically important species, especially Acacia hybrid. A sterilization is one of the most important steps in tissue culture. The aim of this work was to examine the optimal kind and concentration of surface sterilization method and establish an efficient propagation system for Acacia hybrid using tissue culture technique. In this work, we studied a surface sterilization methodology and in vitro propagation of $A$. hybrid. In vitro propagation of the Acacia hybrid using tissue culture technique have an importance for genetic engineering work, bioenergy research and forestry industry in Thailand.

\section{Materials and Methods}

\section{Collection of Plant Materials}

Branch from mother plant of Acacia hybrid was used as explant source. The branch was collected from the hedge orchard of Kasetsart Agricultural and Agro-industrial Product Improvement Institute (KAPI), Thailand. A branch selection method, the branch of $A$. hybrid for tissue culture must obtain $15-20 \mathrm{~cm}$ in height, straight form, and healthy leaves. Then using sharp knife to divide each branch (Figure 1).

The branch was washed under running tap water by a soft brush. The branch was cut into nodal segments $(5 \mathrm{~cm}$ in length), and washed under running tap water for 5 minutes, and rinsed with distilled water. The nodal segments were soaked with $20 \%$ dishwashing liquids for 1 minute and washed 4-5 times in sterile distilled water.

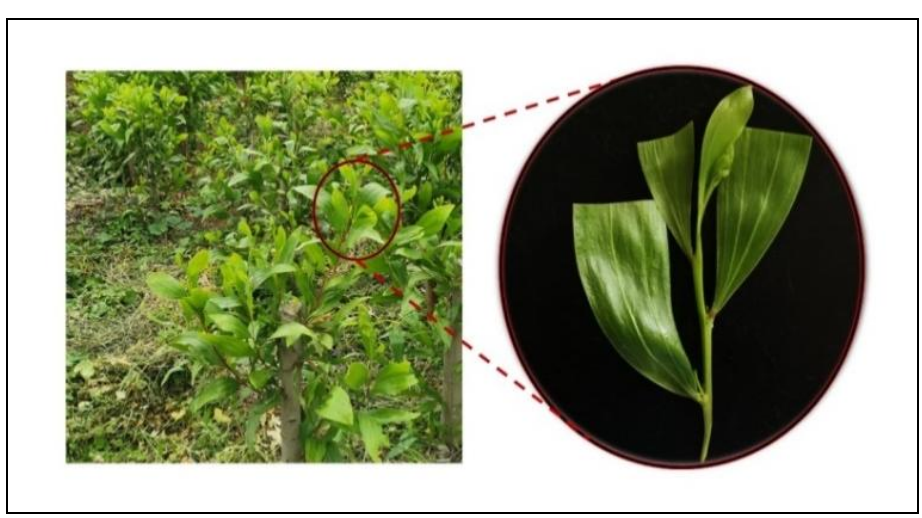

Figure 1: Branch selection from mother tree.

\section{Specimen Sterilization}

Nodal segments were sterilized with $70 \%(\mathrm{v} / \mathrm{v})$ ethanol for 30 seconds. The alcohol was decanted by washing the explants with sterile distilled water and followed by surface sterilization with different concentrations of disinfectant.

The nodal segment was sterilized with different concentrations of Clorox ${ }^{\circledR}(5,10$, and $15 \%)(\mathrm{v} / \mathrm{v})$ for 10 minutes and with different concentrations of mercuric chloride $\left(\mathrm{HgCl}_{2}\right)(0.05$ and $0.1 \%(\mathrm{w} / \mathrm{v})$ for 5 and 10 minutes, separately (Table 2). Clorox ${ }^{\circledR}$ and $\mathrm{HgCl}_{2}$ solution prepared in autoclaved distilled water. Clorox ${ }^{\circledR}$ was used for first and second treatments. Mercuric chloride was used for surface sterilization in third treatment - sixth treatment. The solutions were removed after surface sterilization. The sterilized explants were thoroughly washed with sterile distilled water for four times under aseptic conditions in a laminar airflow cabinet.

Data on contamination, dead explant and survival percentages were recorded. The following formula has been applied for calculation of percentage.

$\%$ Contamination $=\begin{aligned} & \begin{array}{l}\text { Number of contaminated } \\ \text { explants }\end{array} \\ & \text { Total number of explants } \\ & \% \text { Dead explant }= \\ & \% \text { Survival }=\end{aligned} \quad \frac{\text { Number of dead explants }}{\text { Total number of explants }} \times 100$
$\frac{\text { Number of survived explants }}{\text { Total number of explants }} \times 100$

The sterilized explants were placed on a sterilized petridish covered with autoclaved tissue paper to remove excess moisture present on the surface of explants before cultivation. A total of 480 explants were used in all treatments with ten replicates of one explant each for surface sterilization experiment.

- $\quad$ Treatment 1: $10 \%$ Clorox $^{\circledR}$ (0.5 sodium hypochlorite) for 10 minutes $+5 \%$ Clorox $^{\circledR}(0.25$ sodium hypochlorite $)$ for 10 minutes 
- Treatment 2: $15 \%$ Clorox $^{\circledR}$ (0.75 sodium hypochlorite) for 10 minutes $+10 \%$ Clorox $^{\circledR}$ ( 0.5 sodium hypochlorite) for 10 minutes

- Treatment 3: $0.05 \% \mathrm{HgCl}_{2}$ for 5 minutes

- Treatment 4: $0.05 \% \mathrm{HgCl}_{2}$ for 10 minutes

- Treatment 5: $0.1 \% \mathrm{HgCl}_{2}$ for 5 minutes

- Treatment 6: $0.1 \% \mathrm{HgCl}_{2}$ for 10 minutes

\section{Media Preparation}

Modified 1/2MS (Murashige and Skoog, 1962) medium supplemented with $30 \mathrm{~g} / \mathrm{l}$ sucrose $+15 \mathrm{mg} / \mathrm{l}$ Riboflavin $+0.7 \%$ (w/v) Agar was used for tissue culture after surface sterilization. The $\mathrm{pH}$ of medium was adjusted to 5.8 with $1 \mathrm{~N}$ $\mathrm{HCl}$ and $1 \mathrm{~N} \mathrm{NaOH}$. The culture medium was poured into the bottom of the glass culture bottles $(6 \mathrm{~cm}$ in diameter and 11 $\mathrm{cm}$ height). All media were sterilized by autoclaving at $15 \mathrm{lbs}$ pressure, $121^{\circ} \mathrm{C}$ for 20 minutes.

Each explant from all treatments was placed on the culture medium. The cultures were kept at $25 \pm 2^{\circ} \mathrm{C}$ in darkness and maintained in a clean culture room for 4 weeks. Shoot length, leaf length, and number of leaves in all treatments were measured and morphological changes were recorded at 7,14 , 21 , and 28 days of cultures.

\section{Shoot Multiplication From Axillary Buds}

The axillary bud from microshoot was cultured on modified MS medium (Murashige and Skoog, 1962) supplemented with $0.5 \mathrm{mg} / \mathrm{l} \mathrm{BAP}+0.6 \mathrm{mg} / 1 \mathrm{NAA}+0.3 \mathrm{mg} / \mathrm{l}$ PVP to induce multiple shoots for 8 weeks. The medium was adjusted to $\mathrm{pH} 5.7$ before autoclaving at $120{ }^{\circ} \mathrm{C}$ for 20 minutes. The medium was supplied with $0.7 \%(\mathrm{w} / \mathrm{v})$ Agar. Twenty five milliliters of the medium was poured into a culture bottles. All cultures were maintained under a $16 \mathrm{~h}$ of photoperiod with luminous intensity of approximately 50 $\mu \mathrm{mol} \mathrm{m} \mathrm{m}^{-2} \mathrm{~s}^{-1}$ emitted from cool fluorescent tubes (standard culture conditions) at $25 \pm 2{ }^{\circ} \mathrm{C}$. Young plantlet regenerated from a microshoot after 4 weeks on MS medium free of PGRs and induce to elongation.

\section{Statistical Analysis}

Data were statistically analyzed using SPSS. One-way analysis of variance (ANOVA) was used. When significant differences in ANOVA were found, means were compared using the Tukey's post-hoc test at the 5\% probability level.

\section{Results and Discussion}

\section{Surface Sterilization Technique}

Results revealed that the different type, concentration, and duration of disinfectants for surface sterilization of Acacia hybrid had effect on contamination, dead explant, and survival percentages of explants. There was significantly different all treatments in the percentage of contamination, death, survival, and growth performance on $1 / 2$ MS media after 4 weeks $(\mathrm{P}<0.05)$. The present finding revealed that the optimal surface sterilization procedure of Acacia hybrid was sixth treatment, $70 \%(\mathrm{v} / \mathrm{v})$ Ethanol for 30 seconds $+0.1 \% \mathrm{HgCl}_{2}$ for 10 minutes and rinsed in 4 changes of sterile distilled water.

The result showed that using $0.1 \% \mathrm{HgCl}_{2}$ for 10 minutes was the best result (T6). After 4 weeks of cultures, it provided the highest of survival percentage $(86.50 \pm 9.26)$. The percentage of contamination in this treatment was $13.50 \pm 9.26$ (Table 1). The shoot length, leaf length, and number of leaves after sterilization with this method was $3.40 \pm 0.20 \mathrm{~cm}$, $5.04 \pm 0.70 \mathrm{~cm}$. and $3.3 \pm 0.48$ no./explant, respectively (Table 2). Microshoot was observed after 3 days and the leaf length of microshoot tends to increase since then (Figures 2, 3). Fourth treatment showed that the shoot length, leaf length, and number of leaves of explant was $3.40 \pm 0.21 \mathrm{~cm}, 5.03 \pm 0.69 \mathrm{~cm}$. and $3.1 \pm 0.31$ no./explant, respectively. The results showed that using $\mathrm{HgCl}_{2}$ for 10 minutes was the best result. However, the result showed that the contamination of explant was no different when used $0.05 \%$ and $0.1 \% \mathrm{HgCl}_{2}$ for 10 minutes. While explant from third treatment to fifth treatment which use $\mathrm{HgCl}_{2}$ for 5 minutes for surface sterilization was more infectious than 10 minutes (Table 2). However, the growth of explant after 4 weeks from use of $\mathrm{HgCl}_{2}$ to sterilize (treatments 3-6) were not significantly different. First and second treatments showed that the shoot length, leaf length, and number of leaves were less developed than others (Table 2). The percentage of contaminated explants from use of Clorox ${ }^{\circledR}$ was extremely high $(12.50 \pm 8.33)$ (Table 1). 


\begin{tabular}{|c|c|c|c|c|c|}
\hline Treatments & First sterilization & $\begin{array}{c}\text { Second } \\
\text { sterilization }\end{array}$ & $\begin{array}{c}\text { \%Survived } \\
\text { explants }\end{array}$ & $\begin{array}{c}\text { \% Contaminated } \\
\text { explants }\end{array}$ & $\begin{array}{c}\text { \%Dead } \\
\text { explants }\end{array}$ \\
\hline $\mathrm{T} 1$ & $\begin{array}{c}10 \% \text { Clorox }^{\circledR} \\
\text { for } 10 \text { minutes. }\end{array}$ & $\begin{array}{c}5 \% \text { Clorox }^{\circledR} \\
\text { for } 10 \text { minutes. }\end{array}$ & $12.50 \pm 8.33^{\mathrm{d}}$ & $87.50 \pm 8.33^{\mathrm{d}}$ & 0 \\
\hline $\mathrm{T} 2$ & $\begin{array}{c}15 \% \text { Clorox }^{\circledR} \\
\text { for } 10 \text { minutes. }\end{array}$ & $\begin{array}{c}10 \% \text { Clorox }^{\circledR} \text { for } \\
10 \text { minutes. }\end{array}$ & $30.00 \pm 6.45^{\mathrm{c}}$ & $70.00 \pm 6.45^{\mathrm{c}}$ & 0 \\
\hline $\mathrm{T} 3$ & $\begin{array}{c}0.05 \% \mathrm{HgCl}_{2} \\
\text { for } 5 \text { minutes. }\end{array}$ & - & $72.50 \pm 7.90^{\mathrm{b}}$ & $27.50 \pm 7.90^{\mathrm{b}}$ & 0 \\
\hline $\mathrm{T} 4$ & $\begin{array}{c}0.05 \% \mathrm{HgCl}_{2} \\
\text { for } 10 \text { minutes. }\end{array}$ & - & $80.00 \pm 8.74^{\mathrm{ab}}$ & $20.00 \pm 8.74^{\mathrm{ab}}$ & 0 \\
\hline $\mathrm{T} 5$ & $\begin{array}{c}0.1 \% \mathrm{HgCl}_{2} \\
\text { for } 5 \text { minutes. }\end{array}$ & - & $76.50 \pm 12.34^{\mathrm{b}}$ & $23.50 \pm 12.34^{\mathrm{b}}$ & 0 \\
\hline $\mathrm{T} 6$ & $\begin{array}{c}0.1 \% \mathrm{HgCl}_{2} \\
\text { for } 10 \text { minutes. }\end{array}$ & - & $86.50 \pm 9.26^{\mathrm{a}}$ & $13.50 \pm 9.26^{\mathrm{a}}$ & 0 \\
\hline
\end{tabular}

*Means \pm SD values within a column followed by the different superscript letters are significantly different $(\mathrm{p}<0.05)$

Table 1: Percentage of survived explants, contaminutesated explants and dead explants after sterilization using various concentrations of sterilizing agents for 4 weeks on $1 / 2$ MS medium.

\begin{tabular}{|c|c|c|c|c|}
\hline Treatments & Sterilizing agents & Shoot length (mm) & Leaf length (mm) & Leaves (no./plant) \\
\hline $\mathrm{T} 1$ & $\begin{array}{l}10 \% \text { Clorox }^{\circledR} \\
+5 \% \text { Clorox }^{\circledR}\end{array}$ & $3.31 \pm 0.16^{\mathrm{b}}$ & $4.68 \pm 0.48^{b}$ & $3.0 \pm 0.47^{\mathrm{a}}$ \\
\hline $\mathrm{T} 2$ & $\begin{array}{c}15 \% \text { Clorox }^{\circledR} \\
+10 \% \text { Clorox }^{\circledR}\end{array}$ & $3.20 \pm 0.09^{c}$ & $3.74 \pm 0.38^{\mathrm{c}}$ & $2.6 \pm 0.69^{b}$ \\
\hline T3 & $0.05 \% \mathrm{HgCl}_{2}$ & $3.41 \pm 0.17^{\mathrm{a}}$ & $5.04 \pm 0.67^{\mathrm{a}}$ & $3.2 \pm 0.42^{\mathrm{a}}$ \\
\hline $\mathrm{T} 4$ & $0.05 \% \mathrm{HgCl}_{2}$ & $3.40 \pm 0.21^{\mathrm{a}}$ & $5.03 \pm 0.69^{a}$ & $3.1 \pm 0.31^{\mathrm{a}}$ \\
\hline $\mathrm{T} 5$ & $0.1 \% \mathrm{HgCl}_{2}$ & $3.44 \pm 0.23^{\mathrm{a}}$ & $5.10 \pm 0.71^{a}$ & $3.1 \pm 0.56^{\mathrm{a}}$ \\
\hline T6 & $0.1 \% \mathrm{HgCl}_{2}$ & $3.40 \pm 0.20^{\mathrm{a}}$ & $5.04 \pm 0.70^{a}$ & $3.3 \pm 0.48^{\mathrm{a}}$ \\
\hline Means \pm & les within a colu & $\begin{array}{l}\text { wed by the differ } \\
\qquad(\mathrm{p}<0.05)\end{array}$ & erscript letters ar & ificantly different \\
\hline
\end{tabular}

Table 2: Shoot and leaf developments of Acacia hybrid for 4 weeks on $1 / 2$ MS medium. 


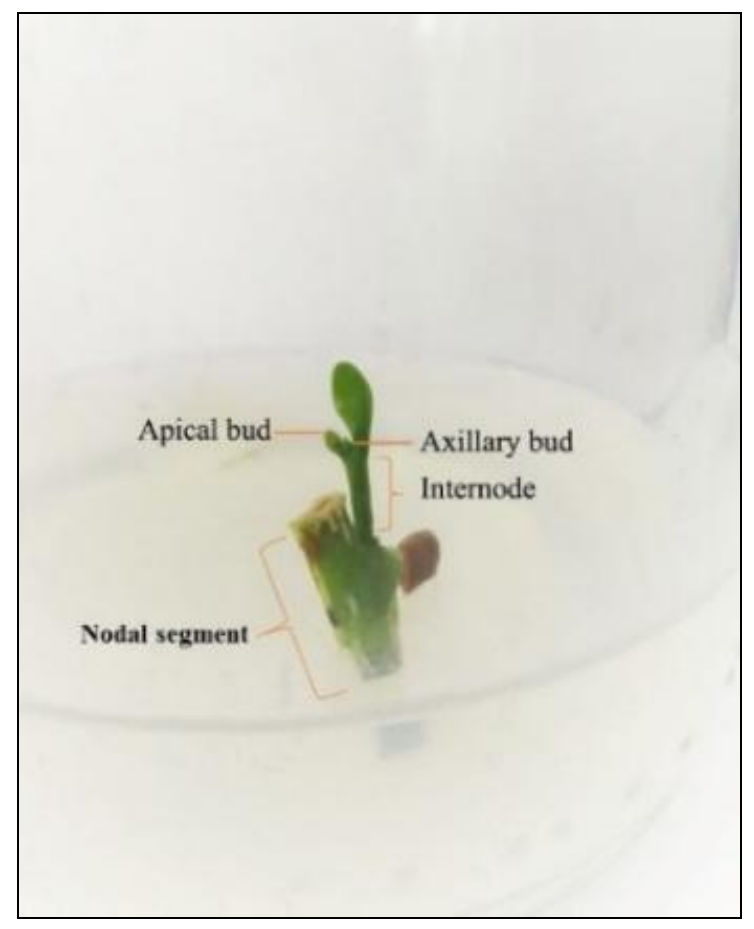

Figure 2: Acacia hybrid on $1 / 2 \mathrm{MS}$ medium after surface sterilization using $0.1 \% \mathrm{HgCl}_{2}$ (sixth treatment) for 1 week in darkness.

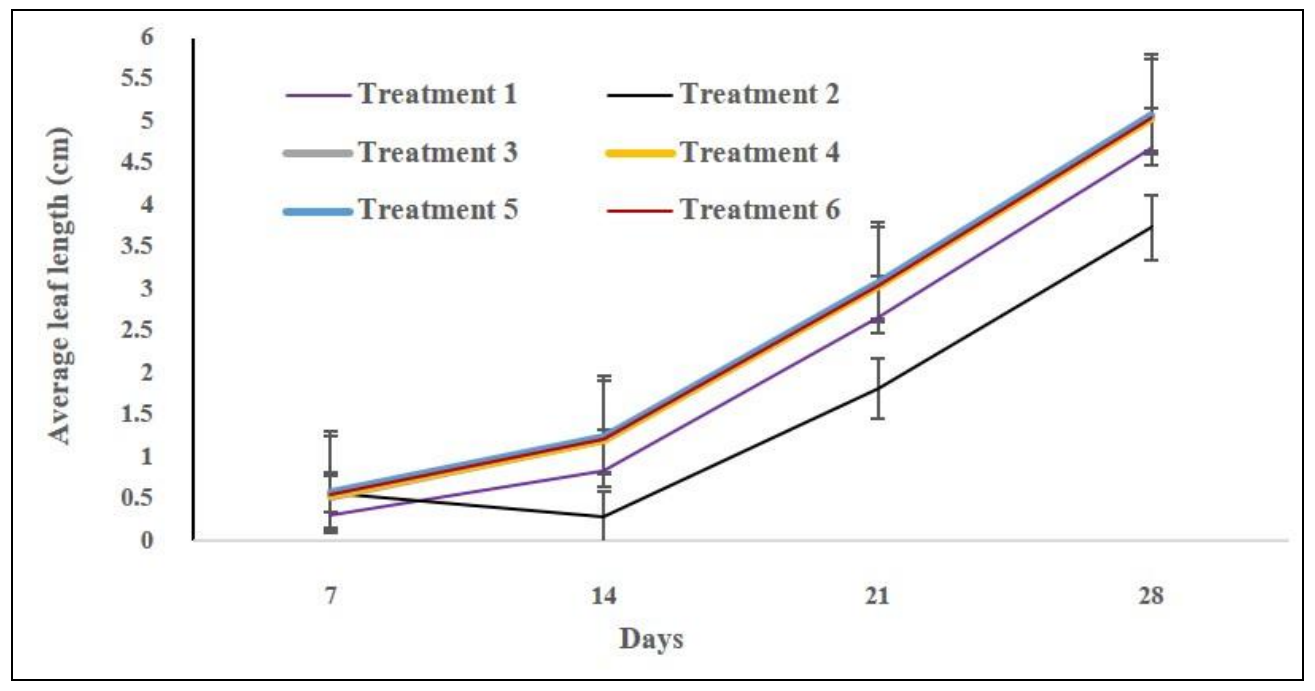

Figure 3: Leaf development of Acacia hybrid after surface sterilization for 28 days (4 weeks).

This sterilization procedure with method from sixth treatment could reduce sterilization process rang from 2-3 steps. The report showed that the surface sterilization of Acacia chundra with $0.1 \% \mathrm{HgCl}_{2}$ for 20 minutes was highly antimicrobial (Rout et al., 2008). Ismail et al (2016) reported that surface sterilization of $A$. auriculiformis had to use both $\mathrm{HgCl}_{2}$ and Clorox ${ }^{\circledR}$. Furthermore, the surface sterilization of $A$. auriculiformis had many procedures, the explant was soaked in $0.1 \%$ Benlate (fungicide) combination with $1 \%$ Boric acid for 24 hours before sterilized with $0.1 \% \mathrm{HgCl}_{2}$ for 10 minutes (first sterilization) and $10 \%$ Clorox $^{\circledR}$ for 5 minutes (second sterilization). Although, mercuric chloride is highly antimicrobial, with action against both bacteria and fungi, it should be used at $0.05-0.1 \%$ for 5-10 minutes (Rathore et al., 2012; Banerjee, 2013; Monteuuis et al., 2013; Nagashree et al., 2015). The sterilization studies of Acacia sp. in many reports showed use of $\mathrm{HgCl}_{2}$ for surface sterilization to reduce tissue loss and to achieve good sterilization results, although there are many toxic compounds. Therefore, the optimal surface sterilization technique of Acacia sp. does not depend only on the kind or concentration of the disinfectant, but also on the preparation method of explants to clean up before sterilized with disinfectants. Therefore, use of $\mathrm{HgCl}_{2}$ at low concentrations (0.05- $0.1 \%)$ is sufficient for the surface sterilization of Acacia hybrid. This may be the reason why some reports prefer to use $\mathrm{HgCl}_{2}$ at $0.05-0.1 \%$. However, mercuric chloride should really 
be avoided, several research laboratories around the world have completely banned its use because it is highly toxic to nearly every other organism.

\section{Shoot Multiplication From Axillary Buds}

In vitro propagation of Acacia hybrid from axillary bud collected from explant which sterilized with surface sterilization technique from sixth treatment. New shoot was initiated on $1 / 2$ Murashige and Skoog (MS) basal medium for 4 weeks in dark condition. The maintenance of shoot cultures in darkness increases the shooting rates. However, when the shoot was maintained in the medium more than 4 weeks, its axillary buds became brunette and later turned brown. Therefore, the Acacia hybrid tissue should be subcultured within 4 weeks.
Axillary bud was developed and maintained by regular subcultures every 4 weeks onto modified MS culture medium supplemented with $30 \mathrm{~g} / \mathrm{l}$ sucrose+7 $\mathrm{g} / \mathrm{l}$ agar+0.6 $\mathrm{mg} / \mathrm{l}$ BAP+0.6 mg/l NAA+0.3 mg/l PVP (Figures 4, 5). The results of shoot multiplication from axillary bud were observed after cultivated for 8 weeks in light condition (Figure 5). Microshoot was produced by axillary buds. The culture showed $100 \%$ multiple shoot formation after culture, $10.5 \pm 1.06$ shoots/explant. The average multiplication rates were 2-3 shoots every 2 weeks. This procedure enhances the capacity for shoot multiplication by axillary bud. The elongated and rooted microshoots from axillary bud were induced on MS medium free of PGRs for 4 weeks (Figure 5D).

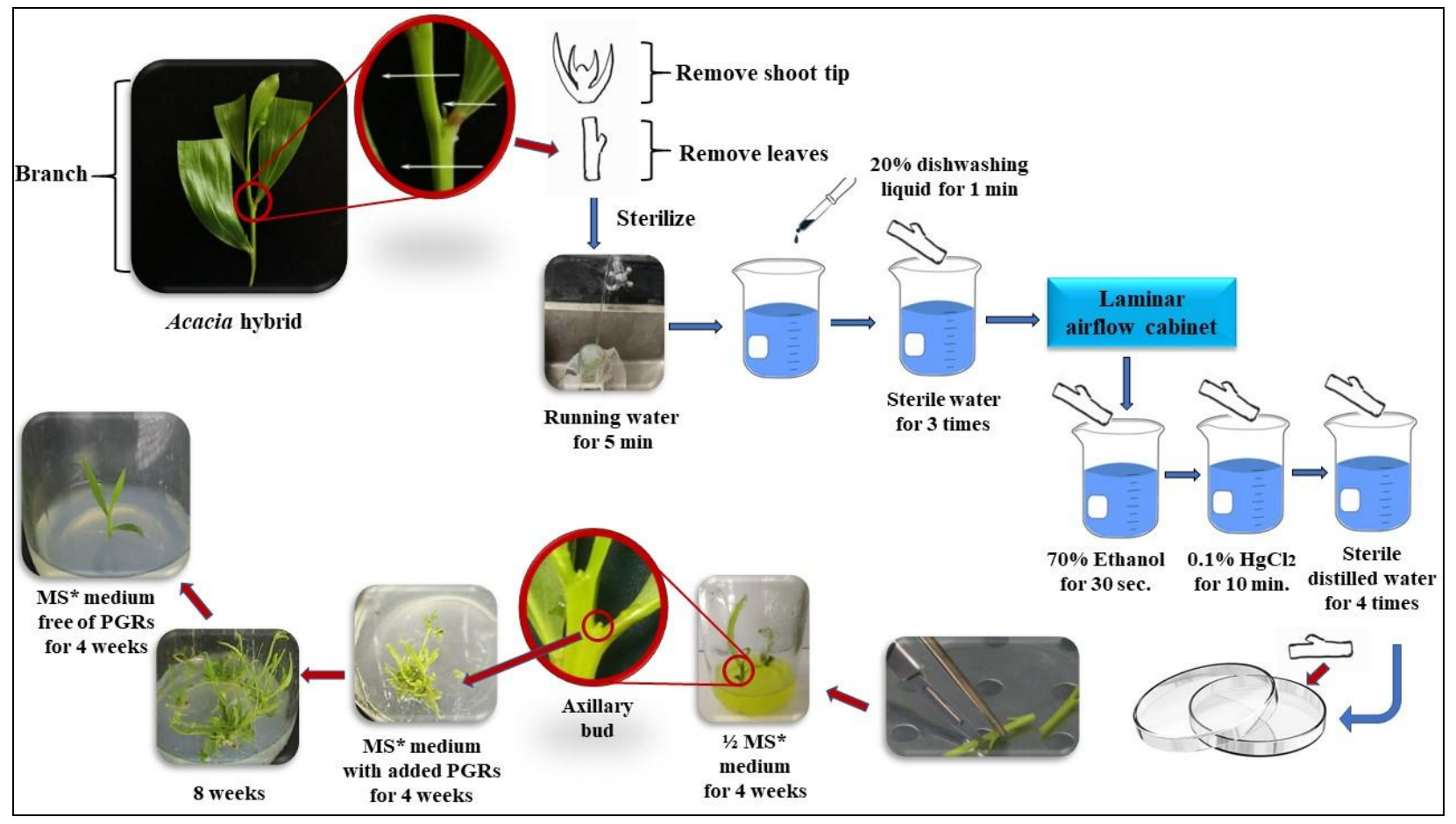

Figure 4: Procedure of the optimal method for in vitro propagation of Acacia hybrid through axillary buds.

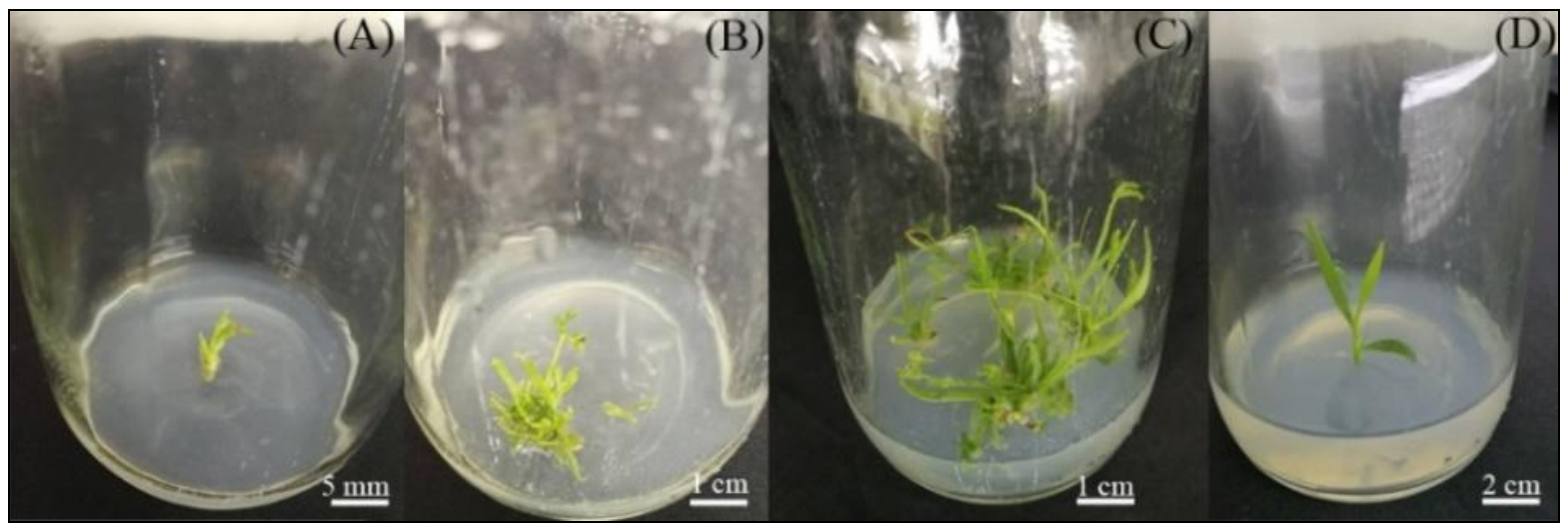

Figure 5: In vitro propagation from axillary buds. (A) the culture after 2 weeks, (B) multiple shoot formation after 4 weeks, (C) shoot multiplication from axillary bud after 8 weeks, (D) the elongated and rooted microshoot on MS medium free of PGRs for 4 weeks. 


\section{Conclusion}

The optimal surface sterilization procedure of Acacia hybrid was rinsed in running water for 5 minutes $+20 \%$ dishwashing liquids $+70 \%(\mathrm{v} / \mathrm{v})$ Ethanol for 30 seconds $+0.1 \%$ $\mathrm{HgCl}_{2}$ for 10 minutes and rinsing with sterile water for 4 times. Multiple shoot induction after cultivating for 8 weeks on MS medium supplemented with $30 \mathrm{~g} / \mathrm{l}$ sucrose $+0.6 \mathrm{mg} / \mathrm{l}$ $\mathrm{BAP}+0.6 \mathrm{mg} / \mathrm{l} \mathrm{NAA}+0.3 \mathrm{mg} / \mathrm{l} \mathrm{PVP}$.

\section{Acknowledgement}

We acknowledge that the research was funded by Kasetsart University Research and Development Institute (KURDI) and Kasetsart Agricultural and Agro-industrial Product Improvement Institute (KAPI).

\section{References}

1. Banerjee P (2013). Rapid in vitro propagation of Acacia auriculiformis on solid and liquid media: role of organic additive, antioxidant and plant growth regulators. Cibtech J. Bio-Protocols. 2:39-49.

2. Corvanich A (1982). Fast growing tree species and concept for forest plantation in Thailand. Forest of Thailand Association, Bangkok.

3. FAO (1982). Seed sources establishment and tree improvement project, Sabah, Malaysia. In Variation in Acacia mangium Willd. (ed. L. Pedley) 41-42.

4. Ismail HS, Kumar M, Aziah MY, Hasnida NH (2016) In Vitro micropropagation of Acacia auriculiformis from selected juvenile sources. Dendrobiology 75:157-165.

5. Kha LD, Nguyen DH, Nguyen VT (1993). Natural hybrid between Acacia mangium and Acacia auriculiformis (in Vietnamese). Forest Journal 7:18-19.

6. Kha LD (2001). Studies on the use of natural hybrids between Acacia mangium and Acacia auriculiformis in Vietnam. Agriculture Publishing, Hanoi.

7. Kha LD, CE Harwood, ND Kien, BS Baltunis, ND Hai, et al. (2012). Growth and wood basic density of Acacia hybrid clones at three locations in Vietnam. New Forests. 43:13-29.

8. Kha LD, HT Ha (2017). Research and development of Acacia hybrids for commercial planting in Vietnam. Vietnam Journal of Science, Technology and Engineering. 59:36-42.

9. Kijkar S (2003). Part II-Species Descriptions Acacia hybrid (A. mangium x A. auriculiformis).4 April 2021, 250-252.

10. Maliwan H, K Haruthaithanasan, E Thanawat, S Phromlert, A Baysangchan (2010). The potential of Leucaena leucocephala, Eucalyptus camaldulensis, Acacia mangium and Acacia spp. (mangium $x$ auriculaeformis) as plantation crops for energy. In Proceedings of 48th Kasetsart University Annual Conference: Plants, 3-5 February 2010, Kasetsart University, Bangkok.

11. Marashige T, Skoog F (1962). A revised medium for rapid growth and bioassays with tobacco tissue culture. Physiol. Plant. 15:473-497.

12. Monteuuis O, Galiana A, Goh D (2013). In Vitro propagation of Acacia mangium and A. mangium $x A$. auriculiformis. In: Maurizio L. (Eds.). Protocols for Micropropagation of Selected Economically-Important Horticultural Plants, Methods in Molecular Biology. Springer. NY, USA. 199-211.

13. Nagashree BR, Santosh Kumar HS, Gurumurthy BR, Nataraja Karaba N, Shivannai MB (2015). PCR-based RAPD technique to determinutese induced salinity tolerance in vitro in Acacia auriculiformis. Plant Biosyst. 149:15-23.

14. Rathore JS, Rai MK, Shekhawat NS (2012). Induction of somatic embryogenesis in gum arabic tree [Acacia senegal (L.) Willd.]. Physiol. Mol. Biol. Plants. 18:387392.

15. Rout GR, Senapati SK, Aparajeta S (2008). Micropropagation of Acacia chundra (Roxb.) DC. Hort. Sci. (prague) 35:22-26.

16. Skomen RG (1986). Acacia (Acacia koa Gray). In: Biotechnology in Agriculture and Forestry, vol Tree 1. Springer, Berlin 375-383.

Citation: Tongkok P, Chusrisom J, Sookpiboon P, Tanavat E, Badan P, et al. (2021) In Vitro Propagation of Acacia Hybrid from Axillary Buds. Adv Agri Horti and Ento: AAHE-150. 